\title{
NAUJOJI VIEŠOJI VADYBA - KAIP POSTMODERNIOS VARTOTOJIŠKOS KULTŪROS PRODUKTAS?
}

\author{
Arvydas Guogis \\ Mykolo Romerio universitetoPolitikos ir vadybos fakulteto \\ Viešojo administravimo institutas \\ Valakupių g. 5, LT-10101 Vilnius, Lietuva \\ Tel. (+370 5) 2740634 \\ Elektroninis paštas: arvydasg@mruni.eu \\ Adomas Vincas Rakšnys \\ Mykolo Romerio universiteto Politikos ir vadybos fakulteto \\ Viešojo administravimo institutas \\ Valakupių g. 5, LT-10101 Vilnius, Lietuva \\ Tel. (+370 5) 2740634 \\ Elektroninis paštas: e_cnv@yahoo.com
}

Pateikta 2014 m. gegužès 17 d., parengta spausdinti 2014 m. rugsejo 27 d.

doi:10.13165/SMS-14-6-2-07

Anotacija. Straipsnyje apžvelgiama postmodernizmo kultūrinès paradigmos bruožo vartotojiškumo anatomija, iškristalizuojamos esminès charakteristikos. Atskleidžiama ir įvertinama vartotojiškos logikos įtaka naujosios viešosios vadybos koncepcijos formavimuisi ir jos struktūrai. Atlikus teorinę analizę, paaiškejo, kad naujojoje viešojoje vadyboje persismelkianti postmodernistine vartotojiška logika diktuoja tai, jog valstybès valdyme viešojo sektoriaus institucijos redukuojamos iki verslo kompaniju statuso, kuriu efektyvumo kriterijais tampa kiekybiniai rodikliai, valstybès tarnautojai pradedami traktuoti kaip žmogiškieji ištekliai, o pačios institucijos keičia orientaciją iš piliečio $i$ klientą. Atskleidus neigiamas naujosios viešosios vadybos ir vartotojiškumo samplaikos

Socialinių mokslų studijos / Societal Studies

(C) Mykolo Romerio universitetas, 2014

(C) Mykolas Romeris University, 2014
ISSN 2029-2244 (online)

http://www.mruni.eu/lt/mokslo_darbai/SMS/ http://www.mruni.eu/en/mokslo_darbai/SMS/ 
implikacijas valstybiniam valdymui, pasiūloma pažangesnè naujojo viě̌ojo valdymo alternatyva, akcentuojanti socialinio teisingumo, skaidrumo, bendradarbiavimo ir moralinès dimensijos svarba.

Reikšminiai žodžiai: postmodernizmas, naujoji viešoji vadyba, naujasis viešasis valdymas, vartotojiškumas, viešasis administravimas.

\section{Ivadas}

Valstybės valdymas perejo ịvairias fazes ir patirtis, transformuojantis kolektyvinei sąmonei, kartu su laiko dvasia vyko ir naujų valdymo metodų paieškos bei jų stadijų evoliucija. Poreikis sukurti demokratišką ir ị viešąjį interesą orientuotą, bet kartu ir ekonomiškai efektyvų bei racionalų valstybinio valdymo instrumentarijų išlieka ne mažiau aktualus ir sudètingas uždavinys šių dienų viešajam administravimui. Siekiant atrasti optimalaus valdymo metodus, nederètų susitelkti vien $\mathfrak{x}$ vadybinius, teisinius ar politinius parametrus. Ne mažiau yra svarbu ịvertinti ir sociologinius, kultūrinius aspektus, kurie gali turèti įtakos viešojo administravimo reformų procesams naujų, dar besiformuojančių teorinių konstruktų igyvendinimo sẻkmei. Tai tampa ypatingai svarbu, pabrèžiant anglosaksiškose šalyse vykusią viešojo administravimo koncepcijų kaitą, pereinant nuo tradicinès, modernizmo kultūroje susiformavusios racionaliosios, véberinès biurokratijos prie naujosios viešosios vadybos modelio, kurio struktūroje, autorių požiūriu, atsiskleidžia vartotojiškumas (angl. consumerism) vienas iš viešajam administravimui būdingų destruktyvių postmodernizmo bruožų. Postmodernizmu (angl. postmodernism) šiame kontekste laikysime kultūrinę paradigmą, kurios chronologinė genezé dažniausiai sietina su antimodernistinėmis laikysenomis, plataus spektro intelektualinèmis transformacijomis, kurios prasidejo $\mathrm{XX}$ amžiaus antrojoje pusėje ${ }^{1}$. Naujoji viešoji vadyba (angl. New Public Management) bus traktuojama kaip valdymo receptas, normatyvinis modelis, prasidejęs XX amžiaus devintajame dešimtmetyje ir besiremiantis privataus sektoriaus metodų integracija ị viešąji sektorių, orientuojantis ị rezultatą ir efektyvumą, pagrịstą ekonomine išraiška ${ }^{2}$. Straipsnyje keliamas tikslas įrodyti, jog vartotojiškumas, kaip postmodernios visuomenès bruožas, sąveikauja su naujosios viešosios vadybos koncepcija ir daro ryškią ittaką jos teorinėms nuostatoms bei principams.

Šios teorinès įžvalgos pirmiausiai gali būti aktualios tiems mokslininkams, kurie tobulina viešojo valdymo instrumentarijų ir pateikia priežastis, kodèl derètų atsižvelgti $\mathfrak{i}$ kultūrinę dimensiją (šiame kontekste i vartotojiškumo logiką viešajame administravime), kuri determinuoja orientacijas ił kiekybinius, o ne i kokybinius rodiklius, galinčius turèti neigiamų pasekmių viešųjų paslaugų teikimui. Straipsnio

1 McGuigan, J. Modernity and Postmodern Culture (2nd Edition). Berkshire, GBR: McGraw-Hill Professional Publishing, 2006.

2 Hood, Ch. A Public Management for All Seasons? Public Administration. 1991,Vol. 69, No. 3: 419-422. 
praktinis aktualumas akivaizdus ir politikams, atskleidžiant, kodèl postmodernizmo epochoje, adaptavus vartotojišką, redukcionistinę rinkos logiką, siekiant viešojo sektoriaus institucijų efektyvumo viešosios politikos igyvendinimo kontekste, iš esmès bus sunku išvengti ịtampų tarp kitų viešajam valdymui ne mažiau svarbių struktūrų, tokių kaip trečiojo sektoriaus organizacijos. Šių elementų veiklą yra daug sunkiau ekonomiškai išmatuoti, tačiau tai visiškai nereiškia, jog jų atliekama veikla yra nenaudinga ir jai neturètų būti skiriami finansiniai ištekliai.

Darbo metodai: straipsnyje taikomi literatūros analizès ir sintezès metodai.

\section{Vartotojiškumo samprata ir esminès charakteristikos}

Siekiant suprasti vartotojiškos kultūros fenomeną, esmines priežastis bei komponentus, pirmiausiai yra būtina apibrèžti sąvokas, kurios neturètų būti vartojamos kaip sinonimai, tai yra dichotomizuoti vartojimą (angl. consumption) nuo vartotojiškumo (angl. consumerism). Ivertinus šių sąvokų skirtumus, bus galima susidaryti daug aiškesnị vaizdą apie vartotojiškos kultūros fenomeną ir jos paradoksus. Pirmoji sąvoka - vartojimas - pabrèžia normalią individo būklę, siekiant patenkinti biologiškai determinuotus poreikius. Pasak Dunn, „paprastas vartojimo apibrèžimas galètų būti - ekonominių resursų naudojimas, siekiant patenkinti žmogiškuosius poreikius, isigyjant ir naudojant gerybes ir paslaugas“3. Vadinasi, galime teigti, jog vartojimas yra organiška veikla, kurią taip pat būtų galima puikiai iliustruoti, kaip instrumentą pasitelkiant Abrahamo Maslowo 4 žmogaus poreikių piramidès logiką, išryškinant universalius, evoliucinius fiziologinị ir saugumo poreikių lygmenis, kurie motyvuoja individą šiuos primityvius poreikius patenkinti. Vartojimas tampa būtina sąlyga išgyventi, ad hoc individas nukreipia finansinius išteklius šių poreikių patenkinimo linkme. Tačiau siekdami apibrèžti vartotojiškumą, susiduriame su daug sudètingesne vartojimo konfigūracija, pasižyminčia postmoderniais parametrais. Akademiniame diskurse nèra vienos nuomonès nei dèl vartotojiškumo genezès, nei dèl pačios sampratos, todèl yra paranku pasitelkti anglu sociologo Featherstono ${ }^{5}$ skiriamas tris pagrindines prielaidas, galinčias padèti suprasti vartotojiškumą.

1) Pirmoje perspektyvoje vartojimo kultūra gali būti sietina su kapitalizmo plètra, pirmiausiai prekine gamyba, kuri davė pradžią milžiniškai materializmo kultūrai vartojamų prekių gausos ir jų pirkimo vietų atžvilgiu.

2) Antroji prielaida pasižymi grynai sociologiniu požiūriu, jog pasitenkinimas, kuris gaunamas dèl prekių vartojimo, siejasi su socialiniais žaidimais, o juose pasitenkinimas ir statusas priklauso nuo sugebejimo infliacijos sąlygomis pademonstruoti ir išlaikyti savo išskirtinumą

3 Dunn, R. G. Identifying Consumption: Subjects and Objects in Consumer Society. Philadelphia, PA, USA: Temple University Press, 2008.

4 Maslow, A. H. A Theory of Human Motivation. Psychological Review. 1943, 50(4): 370-96.

5 Featherstone, M. Consumer Culture and Postmodernism. London, GBR: SAGE Publications Inc. (US), 2007. p. 42. 
3) Trečioji perspektyva yra susijusi su emociniu vartotojiškumo pasitenkinimo aspektu, kai svajonès ir troškimai, kurie tampa sveikintini vartotojiškoje kultūroje, yra skatinami vaizdų ir konkrečių vartojimo vietų, sukeliančių tiesioginị fizišką jaudulị ir estetinį malonumą.

Pirmasis aspektas akcentuoja tai, jog vartotojiškumo šaknys gali būti kildinamos iš kapitalizmo pažangos. Tai numato, jog ne vien kapitalizmas, bet ir vartotojiškumas gali būti sietinas su Vakarų pasauliu. Vadinasi, galima teigti, jog masinè gamyba buvo prekių infliacijos priežastis, o tai transformavo visuomeninę orientaciją iš kokybinès i kiekybinę. Kapitalistinè logika nulèmè masinès konkurencijos, individualizmo ir materializmo kultūros suvešejimą, ekonomiškai apčiuopiamų gèrybių kultą. Ši situacija lèmé tai, jog postmodernioje visuomenejje, sutinkant su Stearnsu, didžioji populiacijos dalis privalo turèti pakankamai pinigų, bent jau kai kada, kad galètų pirkti daugiau, nei jiems yra reikalinga ${ }^{6}$. Antrasis Featherstono faktorius akcentuoja prekių kaip identiteto formavimo strategijos tipą. Tuo tikslu postmodernioje viešojoje erdvejje eskaluojami imperatyvai, kaip, pavyzdžiui, sukurti ir patobulinti save vartojant ar įsigyjant tam tikras prekes ar paslaugas. Būtent šie reikalavimai vartotojiškoje visuomenèje suformuoja kolektyvinị psichologinị kompleksą, kurị galima šiek tiek sumažinti pritampant ar išsiskiriant, taip pat, atsidavus vartotojiškai logikai, pademonstruoti savąji statusą. Vis dèlto Mansveltas ${ }^{7}$ teigia, jog ši mąstymo forma néra visiškai naujas reiškinys. Anot Mansvelto, ji gali būti sietina netgi su romantizmo vertybėmis, estetika ir fiziniu grožiu - kaip asmens unikalumo išraiška. Tokiu atveju būtų galima teigti, jog postmodernizme ne vien sukuriamos naujos gyvenimo formos, bet ir integruojamos senosios, jas demontuojant ir pritaikant šių dienų logikai. Trečiasis veiksnys vartotojiškumą traktuoja kaip grynai emocinio pasitenkinimo priežastị. İvykdant vartotojiškos kultūros reikalavimus, ịsigyjant tam tikras prekes, patiriamas psichologinis pasitenkinimas, ịprasminantis individų egzistenciją. Akcentuotina ir tai, jog vartotojiškumo kontekste ne vien įsivyrauja kiekybiniai rodikliai, tačiau deformuojasi ir kokybės samprata, kai sureikšminamos patyrimo ir estetikos dimensijos. Sutinkant su Hjorth'u ir Kostera ${ }^{8}$, postmodernioje visuomenejje mes nesiekiame ịsigyti namų apyvokos daiktų dèl jų techninių parametrų. Daiktai ịsigyjami, pasiduodant jų gundymams ir ịsimylèjimo pojūčiui. Vartotojiškumo kontekste ne tik keičiasi orientacija kokybės ir kiekybės atžvilgiu, bet ir pati kokybės sąvoka igauna naują prasmę, kuri remiasi estetika ir jos sukeliamomis emocijomis, o ne realiomis, praktinėmis įsigyjamo objekto charakteristikomis.

Siekiant atskleisti vartotojiškumo charakteristikas, galimi ir kitokio pobūdžio akcentai, labiau pabrèžiant poveikị visuomenei bei jos vystymuisi. Ypatingos svar-

6 Stearns, P. N. Stages of Consumerism: Recent Work on the Issues of Periodization. The Journal of Modern History. 69.1. Jstor. The University of Chicago Press. Web. 13 Oct. 2001, p. 102-117.

7 Mansvelt, J. Geographies of Consumption. London, GBR: SAGE Publications Inc. (US), 2005, p. 35.

8 Hjorth, D.; Kostera, M. Entrepeneurhsip and the Experience Economy. Frederiksberg, Copenhagen, DNK: Copenhagen Business School Press, 2007, p. 117 
bos yra lenkų sociologo ir vartotojiškumo anatomo Zygmunto Baumano siūlomas apibréžimas. Anot Baumano, „vartotojiškumas yra socialinės sanklodos tipas, susiklostantis perdirbant kasdienius, nuolatinius ir nuo režimo nepriklausomus norus, troškimus bei geismus ị pagrindinę visuomenès varomąją jẻgą, kuri koordinuoja sistemos reprodukciją, socialinę integraciją, socialinę stratifikaciją ir žmogiškųjų individų formavimąsi, taip pat vaidina pagrindinị vaidmenị individų ir grupių saviidentifikacijos procesuose bei jiems renkantis ir igyvendinant individualią gyvenimo strategiją “9 . Baumanas iš esmès apibendrina pagrindines vartotojiškumo charakteristikas ir išskiria psichologinį troškimų ir pasitenkinimų aspektą, kai socialinė diferenciacija tampa priklausoma nuo individų sugebejimų atsiduoti vartotojiškiems reikalavimams bei identiteto problematikai. Daugeli šių aspektų visuomenèje būtų galima paaiškinti postmodernios būklès diagnoze. Kaip pastebi prancūzų filosofas Loytardas $^{10}$, postmodernizme yra nebepasitikima nei racionaliaisiais, nei dvasiniais metadiskursais. Galime daryti prielaidą, jog, atsisakius atraminių visuomeninių struktūrų, postmoderni kultūra sukuria savo meta - gyvenimo formą - vartotojiškumą. Ši forma nukreipia individų aspiracijas ir sąmonès srautus infliacinio vartojimo linkme, užpildydama tuštumą, kuri atsiranda po modernizmo nesėkmių, tapdama nauja visuomenès varomąja jèga. Siekiant dar labiau išryškinti atotrūkị tarp vartojimo ir vartotojiškumo, ir vẻl paranku pasitelkti Maslowo žmogaus poreikių piramidès struktūrą. Vartotojiškumas ne tik sukelia infliaciją žemesniuose poreikių lygmenyse, bet ir peržengia sferą, ị kurią vartojimas niekada nepretendavo. Postmodernioje visuomenejje aukštesnieji žmogaus socialiniai ir savivertès poreikiai taip pat tampa vartotojiškumo įrankiais. Žmogiškųjų santykių sfera transformuojasi - anksčiau šiuos poreikius buvo galima patenkinti užmezgant realius socialinius ryšius, jie buvo priklausomi nuo kitų individų. Dabar šie procesai redukuojami iki prekinių socialinių žaidimų, o materializmo kultas tampa jų pagrindu. Individų savivertè postmodernioje kultūroje yra nulemiama sugebejimo ịrodyti vartotojiškąją potenciją ir patị žmogų, jam to nesuvokiant, paverčiant preke ${ }^{11}$.

Atlikus vartojimo ir vartotojiškumo sąvokų analizę išryškejjo esminiai skirtumai tarp a) vartojimo, kaip individualios, organiškos veiklos, ir vartotojiškumo, kaip dirbtinio, postmodernaus kolektyvinès sąmonès imperatyvo ir gyvenimo stiliaus, b) tarp racionalių kokybės kriterijų vartojimo ir kiekybinių rodiklių hiperbolizavimo bei kokybinių rodiklių deformacijos vartotojiškumo kontekste, c) tarp vartojimo kaip proceso, kuriame individas naudojasi prekemis ir paslaugomis, ir vartotojiškumo, kuriame pats vartotojas tampa vartojamąja substancija. Pirmojoje dalyje iškristalizavę vartotojiškumo charakteristikas, antrojoje straipsnio dalyje pabandysime susitelkti ties vartotojiškumo elementų sklaida naujosios viešosios vadybos koncepcijoje.

9 Baumanas, Z. Vartojamas gyvenimas. Vilnius: Apostrofa, 2011, p. 56.

10 Loytard, J. F. La condition postmoderne: Rapport sur le savoir. Paris: Editions de Minuit, 1979.

11 Payne, M; Askeland, G. A. Globalization and International Social Work: Postmodern Change and Challenge. Abingdon, Oxon, GBR: Ashgate Publishing Group, 2008, p. 101. 


\section{Naujosios viešosios vadybos ir vartotojiškumo santykis}

Kaip jau buvo minèta anksčiau, naujoji viešoji vadyba yra viešojo administravimo normatyvinis modelis, kuris remiasi privataus sektoriaus strategijomis, siekiant viešajame sektoriuje sukurti tarpinstitucinę konkurenciją, decentralizaciją, skatinti privatizaciją, dalị viešųjų paslaugų teikimo perleidžiant verslo sektoriui, bei orientuotis ị efektyvumą remiantis ekonominėmis prielaidomis ${ }^{12}$. Pirmasis argumentas dẻl naujosios viešosios vadybos kaip vartotojiškumo produkto susijęs su geografiniu lauku. Istoriniame kontekste, atsižvelgiant ị tradicinio, biurokratinio modelio problematiką, šios koncepcijos pradžia sietina su politinès naujosios dešinès reformomis ir anglosaksiškais kraštais, pavyzdžiui, Margaret Thatcher, Didžiojoje Britanijoje bei Reigano reformas JAV bei sèkmingą šių metodų taikymą Naujojoje Zelandijoje ${ }^{13}$. Naujosios viešosios vadybos reformų pradžia geografiškai mums svarbi dèl to, jog ekonominè kapitalizmo sistema taip pat sietina su anglosaksų šalimis, o vartotojiškumas traktuojamas kaip viena iš kapitalizmo vystymosi pasekmių. Galima daryti prielaidą, jog neatsitiktinai ir naujosios viešosios vadybos reformų genezė yra susijusi būtent su šiomis geografinèmis zonomis. Vadinasi, nederètų stebėtis, jog kultūrose, kuriose istoriškai susiklostė stiprūs individualistiniai, antagonistiniai, konkurencija grịsti santykiai, ekonominės gerovès ir jos kiekybine išraiška gausinimo imperatyvai bei materializmo kaip vertybès kultas, yra tik laiko klausimas, kada šios atraminès vartotojiškos logikos struktūros stichiškai, be didesnių pastangų persismelks ir ị valstybès valdymą. Todèl natūralu, jog nagrinèjant „sèkmingus“ naujosios viešosios vadybos kaip ekonominio efektyvumo valdymo modelio igyvendinimo atvejus akademiniame diskurse dažniausiai išskiriami būtent anglosaksiški kraštai. Jeigu šios prielaidos teisingos, galima teigti, jog būtent šios kultūros neatsiejamos nuo kapitalistinių ekonominių santykių susiformavimo, todèl ir naujosios viešosios vadybos modelio metodikos ten buvo organiškai bei natūraliai ịdiegtos.

Antrasis argumentas remiasi tuo, jog naujosios viešosios vadybos kontekste valstybė „atsidavë“ postmodernistiniam vartotojiškumui, ją redukuojant iki kapitalistinio produkto, kaip analogiją pasitelkiant prekybos centrą, atliekantị viešąsias funkcijas. Prekybos centro efektyvumo kriterijai yra orientuoti i parduodamos produkcijos kiekí, ir kuo daugiau prekių ar paslaugų yra parduota, tuo jo savininkams generuojamas didesnis pelnas. Todèl prekybos centre prioritetas yra kiekybiniai rodikliai, visiškai negarantuojantys kokybės. Šią logiką naujosios viešosios vadybos fone pritaikius valstybei, išryškèja akivaizdi problema, suvokiant, jog vien tai, kad viešojo sektoriaus institucijos per tam tikrą laiką suteiks didelị kiekị paslaugų, tai visiškai negarantuos, jog „klientai“ bus patenkinti. Yra itin svarbu suvokti, jog kiekis dar nelemia rezultato.

12 Denhardt, J. V.; Denhardt, R. B. New Public Service. Armonk, NY, USA: M.E. Sharpe, Inc., 2007.

13 Barzelay, M. New Public Management: Improving Research and Policy Dialogue. Berkeley, CA, USA: University of California Press, 2001. 
Ypatingai tai tampa aktualu analizuojant tokias viešąsias sritis kaip švietimas, sveikatos apsauga, socialinė sfera, kuriose vartotojiškumas galètų turèti itin destruktyvių padarinių visuomenės nariams. Kita argumento pusė yra ta, jog, skatinant privatizaciją ir anksčiau paminètas sritis perleidžiant vien tik privačiajam sektoriui, neišvengiamai kyla prieštaravimai tarp pamatinių viešojo administravimo tikslų ir naujosios viešosios vadybos reikalavimų. Nors finansines sąnaudas valstybės lygmeniu sumažinti yra immanoma, tačiau labai svarbu atsakyti ị klausimą, kokia visa to kaina? Ar igyvendinant privatizaciją ir suabsoliutinant kiekybinius rodiklius nebus paminamos viešojo administravimo vertybès viešųjų gèrybių teikimo atžvilgiu. Juk akivaizdu, kad tai gali suponuoti vartotojišką verslo struktūrų laikyseną paprastų piliečių atžvilgiu, kai žmogus vertinamas tik pagal savo vartotojišką potenciją, statusą ar reprezentacinius ženklus, taip užkertant kelią tinkamai gauti viešąsias paslaugas. Traktuojant valstybę kaip prekybos centrą ar verslo kompaniją išryškejja ir tarpinstitucinès konkurencijos aspektas tiek finansine, tiek viešosios politikos projektų igyvendinimo prasmèmis ${ }^{14}$. Diegiant naujosios viešosios vadybos metodus buvo tikimasi, jog konkurencija turètų pagerinti viešųjų paslaugų kokybę, tačiau postmodernistiniame vartotojiškumo kontekste konkurencinè aplinka viešajame sektoriuje gali sukelti konfliktines situacijas, o ne tobulinti tarpinstitucinę kooperaciją, kuri yra būtinas komponentas darniam ir optimaliam valdymui. Todèl Noordhoekas ir Saneris ${ }^{15}$ teisingai pastebi, jog valstybès redukcija iki verslo kompanijos statuso yra neigiamas reiškinys viešajame administravime. Pritariant autoriams yra būtina suvokti, jog valstybès ir verslo misija skiriasi, taip pat galima teigti, jog valstybès pavertimas verslo kompanija yra neigiamas reiškinys, pasižymintis ryškiomis vartotojiškumo savybėmis.

Trečiasis argumentas yra orientuotas ị požiūrio kaitą dèl valstybès tarnautojo misijos viešojo administravimo modelių transformacijos kontekste. Tradicinio biurokratinio modelio struktūroje buvo įtvirtinami principai, siekiant valstybès tarnautojui užtikrinti daugybę garantijų ir privilegijų, tokių kaip ilgalaikès darbo perspektyvos, galimybė kilti karjeros laiptais, atlyginimas, nepriklausantis nuo rezultatų, aiškiai apibréžta veiklos sritis ${ }^{16}$. Naujoji viešoji vadyba, autorių nuomone, kaip vartotojiškas produktas, siekdama pakeisti „neefektyvią" valdymo aparato būklę, ịveda savo principus, pirmiausiai išbalansuodama iki tol nusistovejjusią biurokratinio modelio struktūrą. Naujosios viešosios vadybos kontekste valstybès tarnautojai pradedami traktuoti kaip „Žmogiškieji ištekliai“17. Pats žodis „„štekliai“ pirmiausiai pabrèžia tai, jog yra sukuriamas ịspūdis, jog valstybès tarnautojas, kaip ir visi kiti objektai vartoto-

14 Osborne, D.; Gaebler, T. Reinventing Government: How the Entrepreneurial Spirit is Transforming the Public Sector. Reading, MA: Addison-Wesley, 1992.

15 Noordhoek, P.; Saner R. Beyond New Public Management: Answering the Claims of both Politics and Society. Public Organization Review: AGlobal Journal. 2005, p. 35-53.

16 Weber, M. Economy and Society: An Outline of Interpretive Sociology. Berkley, CA: U. California Press, 1978.

17 Thom, N.; Ritz, A. Viešoji vadyba. Inovaciniai viešojo sektoriaus valdymo metmenys: monografija. Vilnius: Lietuvos teisès universitetas, 2004. 
jiškumo kontekste, yra prekè, kuria galima disponuoti, vykdant kitus vartotojiškumo ciklo imperatyvus, tokius kaip įvertinti, ịsigyti ir išmesti. Tada valdymo kontekste pasitelkiama subtilesnè retorika, kaip atranka, kontraktų sistema ar nekonkurencingumas $^{18}$. Valstybès tarnautojas, kaip ir visos prekès prekybos centre, yra ịvertinamas pagal specifinius kriterijus, siekiant atskleisti jo savybių atitiktį nustatytiems normatyvams. Kita vertus, šiame kontekste išryškẻja ir dar viena naujosios viešosios vadybos dviprasmybè. Viena vertus, sukuriant kontraktų sistemą, nustatant ekonominius efektyvumo kriterijus valstybės tarnautojams ir taip minimizuojant véberinès struktūros privilegijas, išbalansuojama nusistovèjusi struktūra, tačiau kita vertus, kartu su naująja viešąja vadyba stengiamasi integruoti privačiame sektoriuje išpopuliarejjusias ivairiausias humanistines psichologines motyvacijos teorijas, kurios naujosios viešosios vadybos kontekste tarsi turètų patenkinti žmogiškuosius poreikius, kurie ir taip jau buvo reflektuojami tradicinio viešojo administravimo modelio struktūroje. Šis reabilitacinis bandymas išryškina naujosios viešosios vadybos paradoksą, reformuojant tradicinę struktūrą. Vèl yra stengiamasi sugrižti prie jos logikos, pasitelkiant kitus, vadybinius ir psichologinius instrumentus. Tai suprantant yra būtina kelti klausimą, jog galbūt tradicinis, biurokratinis modelis buvo pernelyg intencionaliai demonizuotas, stengiantis viešojo sektoriaus problematikas sufokusuoti ị egzistuojančios sistemos kritiką, kaltę suverčiant ne taikymo praktikai ir realiam šio modelio igyvendinimui, o teoriniams normatyvams ${ }^{19}$. Tačiau kita vertus, taip pat ši bandymą galima pabandyti paaiškinti pasitelkiant ir postmodernizmo filosofo J. Derridos dekonstrukcijos logiką - išardant esamą struktūrą ir vẻl kitomis priemonèmis stengiantis sukurti panašią struktūrą. Postmodernizmo kultūrinès paradigmos fone viską yra būtina dekonstruoti ir ịvertinti iš naujo ${ }^{20}$. Paminètina ir tai, jog su naująja viešąja vadyba, išbalansavus nusistovejusio tradicinio, biurokratinio modelio struktūrą, kartu yra bandomas integruoti žmogiškųjų išteklių požiūris.

Apibendrinant anksčiau pateiktą analizę, galima teigti, jog naujosios viešosios vadybos kontekste iškristalizavus vartotojiškumo apraiškas, išryškejjo, jog tiek kapitalizmo, kaip vieno iš vartotojiškumo kilmės faktorių, tiek naujosios viešosios vadybos genezė yra sietina su anglosaksiškais kraštais. Geografinės sąsajos užtikrino sẻkmingą naujosios viešosios vadybos igyvendinimą ir vartotojiškumo logikos integraciją. Išanalizavus šios koncepcijos struktūrą, taip pat paaiškejjo, jog esmine orientacija naujosios viešosios vadybos reformose tampa požiūris ị pilietị kaip ị klientą, ekonomizaciniai bei kiekybiniai rodikliai, kapitalistinè konkurencija tarp institucijų - taip pagrindžiant vartotojiškumo logiką. Pasitelkiant šią retoriką individas tiesiogiai redukuojamas iki prekès statuso valstybès ir organizacijų atžvilgiu, taip patvirtinant vartotojiškumo kaip postmodernios visuomenès bruožo persismelkimą ị valstybès

18 Peters, T. J.; Waterman, R. H. In Search of Excellence. New York: Harper and Row, 1982.

19 Tumènas, A. Naujoji viešoji vadyba ir jos mitai. Viešoji politika ir administravimas. 2008, 25: 39-50. 
valdymo sferą. Todèl siekiant tobulinti valdymo metodikas būtina suvokti, jog vartotojiškumo bruožai viešajame administravime viešųjų paslaugų teikimo atžvilgiu visuomenei bei trečiojo sektoriaus organizacijoms gali turèti destruktyvių padarinių. Ad hoc valstybė turètų iš naujo ịvertinti, ar visos viešosios sritys ir procesai gali būti redukuojami iki ekonominių išraiškų, vartotojiškos logikos kontekste nulemiančių jų efektyvumą, o tada būtų galima atrasti atsakymą, ar postmodernistiniame viešajame administravime valstybè turètų sekti naujosios viešosios vadybos diktuojama logika?

Naująja viešąja vadyba pasekè ir kiti, ne tik anglosaksiški Vakarų kraštai, tačiau ne visi vienodai. Kai kurie, kaip, pavyzdžiui, prancūziškai kalbančios šalys ar regionai atvirai ją ignoravo. Rytų Europoje, pavyzdžiui, Lietuvoje, buvo pritaikyti tik atskiri naujosios viešosios vadybos metodai ribotam skaičiui organizacijų.

\section{Ar yra kitokių viešojo administravimo alternatyvų?}

Ar galima naujosios viešosios vadybos ir beatodairiško vartotojiškumo samplaiką pakeisti geresne, pažangesne alternatyva? Klausimas ne tik retorinis, bet ir svarbus dabarčiai bei ateičiai - po neoliberalizmo ekonominès krizès, kuri nuvilnijo per Vakarų pasaulį prieš kelis metus ir besiplečiant kultūrinei-moralinei krizei, kuri įsisiūbavo Vakaruose prieš kelis dešimtmečius, kai buvo pasikèsinta ị gerovès valstybès pamatus, reikalinga naujo tipo - skaidri ir atvira sistema, kuriai svarbiausia - skaidrumas, teisingumas, demokratija, bendradarbiavimas, socialinè kokybè ir socialinè atsakomybej ir tik po jų ịvairūs kiekybiškai išmatuojami rezultatai. Ne tik kiekybiškai išmatuojami rezultatai, bet ir procesas turi būti svarbus viešųjų paslaugų kokybei pasiekti. Aišku, kaštų ir naudos analizè turi būti igyvendinta, bet nauda turi būti „matuojama“ pirmiausiai kokybiškai, o tik po to - kiekybiškai, ypač jeigu kalbame apie viešajj sektorių. Viešojo sektoriaus išlikimo ir jo sustiprinimo klausimas sietinas su vartotojiškos kapitalizmo logikos, paremtos socialine rizika ir neprognozuojamumu, apribojimu ir perkeliant valdymo akcentus ị ilgalaikès perspektyvos formavimo klausimus, kuri remtųsi aiškumo, pastovumo ir prognozuojamumo tendencijomis. Veiksmingumas, kaip tikslų pasiekimo laipsnis, socialinis teisingumas, lygybe ir etika turi pirmauti prieš ekonomiškumo ir kiekybinio efektyvumo siekị. Toks jau teoriškai besiformuojantis modelis yra. Tai - naujasis viešasis valdymas (angl. New Governance), kuris pasižymi anksčiau išvardintais principais. I ji gręžiasi viešojo administravimo teorinių ir praktinių konferencijų organizatoriai, žiniasklaida ir kai kurie politikai. Dèmesys naujajai paradigmai yra dar nepakankamas, mažai siūloma konkrečių naujojo viešojo valdymo igyvendinimo metodų, bet ledai jau pralaužti, naujojo viešojo valdymo diskursas suformuotas. Naujajam viešajam valdymui svetima ekonomizuota kalba. Būtų gerai, kad, be ekonomistų, jị interpretuojant ir pagrindžiant plačiau ịsitrauktų ir kitų socialinių mokslų atstovai. Sumaterialejusiame postmodernistiniame pasaulyje yra svarbu didinti naujojo viešojo valdymo ịtaką, kad moralaus ir dvasiškai turtingo politiko, valdininko, mokslininko, žurnalisto ar eilinio piliečio balsas būtų girdimas. Gal tai skamba kaip savotiška T. Moro ar T. Kampanelos utopija, bet be tyresnio ir dvasiškesnio vadybinio normatyvinio modelio igyvendinimo jokie pokyčiai korupci- 
jos mažinimo, etikos, tikro, o ne formalaus pliuralizmo ar nevyriausybinių organizacijų veiklos aktyvinimo kryptimi yra neįmanomi. Senoji, vartotojiška, materialistine naujosios viešosios vadybos paradigma išsisėmè, naujoji dar nesukurta, tačiau jos pradiniai elementai, bent jau teorine prasme, yra apčiuopiami ir matomi.

\section{Išvados}

1. Panagrinejjus vartojimo ir vartotojiškumo bruožus, išryškejo esminiai skirtumai tarp vartojimo kaip natūralios, organiškos veiklos, kuriai tiktų pirminiai Maslowo poreikių piramidès lygmenys, akcentuojant tai, kad vartojimas yra natūralus, evoliucinis procesas, neatsiejamas nuo fiziologinių bei saugumo poreikių patenkinimo ir vartotojiškumo, kaip postmodernios visuomenès bruožo, pasižyminčio imperatyvine logika, orientuota ị infliacinị vartojimą, laikinumą, atitinkamą estetinị patyrimą, kiekybinius kriterijus bei paties žmogaus pavertimą preke.

2. Valstybès organizavime, taikant naująją viešąją vadybą, kuri ignoruoja tradicinę viešojo intereso logiką ir igyja verslo kompanijos tipo organizacijos bruožų, kai orientuojamasi ne ị pilietị, o ị vartotoją kaip klientą, yra suabsoliutinami kiekybiniai rodikliai ir valstybès tarnautojai pradedami traktuoti kaip „žmogiškieji ištekliai“.

3. Iškristalizavus neigiamas vartotojiškumo ịtakas naujosios viešosios vadybos kontekste yra būtina pasirinkti tuos valstybinius, viešojo sektoriaus ir viešojo administravimo prioritetus, kurie mažintų hiperbolizuotos ekonomizacijos keliamą žalą tiek atskiriems visuomenés nariams, tiek ir pačiai valstybei.

4. Viešojo sektoriaus išlikimo ir jo sustiprinimo klausimas sietinas su vartotojiškos kapitalizmo logikos, paremtos socialine rizika ir neprognozuojamumu, apribojimu ir perkeliant valdymo akcentus ị ilgalaikès perspektyvos formavimo klausimus, kuri remtųsi aiškumo, pastovumo ir didesnio prognozuojamumo tendencijomis.

5. Alternatyva naujosios viešosios vadybos ir vartotojiškumo samplaikai turètų tapti humaniškesnis, $\dot{\mathfrak{l}}$ atvirumą, skaidrumą, socialinị teisingumą, socialinę atsakomybę ir socialinę kokybę orientuotas naujojo viešojo valdymo modelis, kuris sumažintų neigiamas vartotojiško globalaus neoliberalaus kapitalizmo įtakas.

\section{Literatūra}

Barzelay, M. New Public Management: Improving Research and Policy Dialogue. Berkeley, CA, USA: University of California Press, 2001.

Baumanas, Z. Vartojamas gyvenimas. Vilnius: Apostrofa, 2011.

Denhardt, J. V.; Denhardt, R. B. New Public Service. Armonk, NY, USA: M.E. Sharpe, Inc., 2007.
Derrida, J. De la grammatologie. Paris: Les Éditions de Minuit, 1967.

Dunn, R. G. Identifying Consumption: Subjects and Objects in Consumer Society. Philadelphia, PA, USA: Temple University Press, 2008.

Featherstone, M. Consumer Culture and Postmodernism. London, GBR: SAGE Publications Inc. (US), 2007. 
Hjorth, D.; Kostera, M. Entrepeneurhsip and the Experience Economy. Frederiksberg, Copenhagen, DNK: Copenhagen Business School Press, 2007.

Hood, Ch. A Public Management for All Seasons? Public Administration. 1991, Vol. 69, No. 3.

Loytard, J. F. La condition postmoderne: Rapport sur le savoir. Paris: Editions de Minuit, 1979.

Malkmes, J. American Consumer Culture and its Society: From F. Scott Fitzgerald's 1920s Modernism to Bret Easton Ellis'1980s Blank Fiction. Hamburg, DEU: Diplomica Verlag, 2011.

Mansvelt, J. Geographies of Consumption. London, GBR: SAGE Publications Inc. (US), 2005.

Maslow, A. H. A Theory of Human Motivation. Psychological Review. 1943, 50(4).

McGuigan, J. Modernity and Postmodern Culture (2nd Edition). Berkshire, GBR: McGraw-Hill Professional Publishing, 2006.

Noordhoek, P.; Saner R. Beyond New Public Management: Answering the Claims of both Politics and Society.
Public Organization Review: AGlobal Journal. 2005.

Osborne, D.; Gaebler, T. Reinventing Government: How the Entrepreneurial Spirit is Transforming the Public Sector. Reading, MA: Addison-Wesley, 1992.

Payne, M; Askeland, G. A. Globalization and International Social Work: Postmodern Change and Challenge. Abingdon. Oxon, GBR: Ashgate Publishing Group, 2008.

Peters, T. J.; Waterman, R. H. In Search of Excellence. New York: Harper and Row, 1982.

Stearns, P. N. Stages of Consumerism: Recent Work on the Issues of Periodization. The Journal of Modern History. 69.1. Jstor. The University of Chicago Press. Web. 13 Oct. 2001.

Thom, N.; Ritz, A. Viešoji vadyba. Inovaciniai viešojo sektoriaus valdymo metmenys: monografija. Vilnius: Lietuvos teisès universitetas, 2004.

Tumėnas, A. Naujoji viešoji vadyba ir jos mitai. Viešoji politika ir administravimas. 2008, 25.

Weber, M. Economy and Society: An Outline of Interpretive Sociology. Berkley, CA: U. California Press, 1978.

\title{
NEW PUBLIC MANAGEMENT: THE PRODUCT OF POST-MODERN CONSUMER CULTURE?
}

\author{
Arvydas Guogis, Adomas Vincas Rakšnys \\ Mykolas Romeris University, Lithuania
}

Summary. The aim of the article is to conduct theoretical analysis trying to show that consumerism, as the feature of post-modern society, interrelates with new public management concept and makes an impact to its theoretical principles. In the first part, the authors reveal the differences between consumption and consumerism and define the main characteristics of consumerism. A. Maslow needs hierarchy pyramid's logic serves 
for that purpose as the instrument. Consumerism aspect is indicated as the natural, organic activity, which is directed to fulfill the lower individ's needs. Consumerism as not natural, postmodern meta-life form not only causes inflation in the lower factors of human needs, but also presses forward to the sphere where consumerism was earlier absent. In postmodern society, the higher human social and self-actualization needs also are becoming the instruments of consumerism. When earlier these needs were satisfied by establishing real social ties and they were dependent on other individs, now the human relations sphere is transforming. These processes are reduced to social plays of trade and the cult of materialism becomes the essential feature. There are also revealed other aspects, such as the use of rational quality criteria and absolutizing of quantitative indicators as well as the deformation of qualitative indicators in the context of consumerism. It is necessary to indicate the understanding of consumerism as the process where individ is using the commodities and services and the consumerism where the consumer becomes the consuming substance.

In the second part, the authors reveal the connection between consumerism and new public management concept by expressing the status of the state as the trade center status and absolutizing the quantitative indicators, orientation towards the client and reduction of state employees to human resources understanding. Human resources in such a model have to submit to the imperatives of consumerism. Many causes could have an impact to the management and consumerism relation, for instance, the geographical factors, economic development of capitalism and neo-liberal streams.

These arising problems pose a necessity in state governance to orientate towards New Governance, as the alternative how to reject the destructive and consumeristic accents of new public management for the sake of society and the state development. Social dimension, which was abandoned by new public management 20-30 years ago while retreating from the welfare state, has to be rediscovered in the new circumstances.

Keywords: postmodernism, new public management, new governance, consumerism, public administration.

Arvydas Guogis, Mykolo Romerio universiteto Politikos ir vadybos fakulteto Viešojo administravimo instituto profesorius. Mokslinių tyrimų kryptys: socialinė apsauga, socialinis administravimas, globalizacija ir socialinè politika, naujasis viešasis valdymas.

Arvydas Guogis, Mykolas Romeris University, Faculty of Politics and Management, Institute of Public Administration, Professor. Research interests: social security, social administration, globalization and social policy, new governance.

Adomas Vincas Rakšnys, Mykolo Romerio universiteto Politikos ir vadybos fakulteto viešojo administravimo magistrantas. Mokslinių tyrimų kryptys: kultūriniai viešojo administravimo pagrindai, naujoji viešoji vadyba ir naujasis viešasis valdymas.

Adomas Vincas Rakšnys, Mykolas Romeris University, Faculty of Politics and Management, Institute of Public Administration, MA student. Research interests: cultural basis for the development of public administration, new public management and new governance. 